\title{
Detection of the East and West African kdr mutation in Anopheles gambiae and Anopheles arabiensis from Uganda using a new assay based on FRET/Melt Curve analysis
}

\author{
Katrijn Verhaeghen ${ }^{* 1}$, Wim Van Bortel ${ }^{1}$, Patricia Roelants ${ }^{1}$, \\ Thierry Backeljau ${ }^{2,3}$ and Marc Coosemans ${ }^{1}$
}

Address: ${ }^{1}$ Departement of Parasitology, Prins Leopold Institute of Tropical Medicine, Nationalestraat 155, B-2000 Antwerp, Belgium, ${ }^{2}$ Departement of Invertebrates, Royal Belgian Institute of Natural Sciences, Vautierstraat 29, B-1000 Brussels, Belgium and ${ }^{3}$ Evolutionary Biology Group, University of Antwerp, Groenenborgerlaan 171, B-2020 Antwerp, Belgium

Email: Katrijn Verhaeghen* - kverhaeghen@itg.be; Wim Van Bortel - wvbortel@itg.be; Patricia Roelants - proelants@itg.be; Thierry Backeljau - thierry.backeljau@naturalsciences.be; Marc Coosemans - mcoosemans@itg.be

* Corresponding author

Published: 22 February 2006

Malaria Journal2006, 5:16 doi:10.1186/1475-2875-5-16

This article is available from: http://www.malariajournal.com/content/5/I/l6

(c) 2006Verhaeghen et al; licensee BioMed Central Ltd.

This is an Open Access article distributed under the terms of the Creative Commons Attribution License (http://creativecommons.org/licenses/by/2.0), which permits unrestricted use, distribution, and reproduction in any medium, provided the original work is properly cited.
Received: 0 I November 2005

Accepted: 22 February 2006

\begin{abstract}
Background: Appropriate monitoring of vector resistance to insecticides is an integral component of planning and evaluation of insecticide use in malaria control programmes. The malaria vectors Anopheles gambiae s.s. and Anopheles arabiensis have developed resistance to pyrethroid insecticides as a result of a mechanism conferring reduced nervous system sensitivity, better known as knockdown resistance (kdr). In An. gambiae s.s. and An. arabiensis, two different substitutions in the para-type sodium channel, a LI0I4F substitution common in West Africa and a LIOI4S replacement found in Kenya, are linked with $k d r$. Two different allele-specific polymerase chain reactions (AS-PCR) are needed to detect these known kdr mutations. However, these AS$\mathrm{PCR}$ assays rely on a single nucleotide polymorphism mismatch, which can result in unreliable results.
\end{abstract}

Methods: Here, a new assay for the detection of knockdown resistance in An. gambiae s.s. and An. arabiensis based on Fluorescence Resonance Energy Transfer/Melt Curve analysis (FRET/MCA) is presented and compared with the existing assays.

Results: The new FRET/MCA method has the important advantage of detecting both $k d r$ alleles in one assay. Moreover, results show that the FRET/MCA is more reliable and more sensitive than the existing AS-PCR assays and is able to detect new genotypes. By using this technique, the presence of the East African kdr mutation (LIOI4S) is shown for the first time in An. arabiensis specimens from Uganda. In addition, a new $k d r$ genotype is reported in An. gambiae s.s. from Uganda, where four An. gambiae s.s. mosquitoes possess both, the West (LIOI4F) and East (LIOI4S) African $k d r$ allele, simultaneously.

Conclusion: The presence of both $k d r$ mutations in the same geographical region shows the necessity of a reliable assay that enables to detect both mutations in one single assay. Hence, this new assay based on FRET/MCA will improve the screening of the $k d r$ frequencies in An. gambiae s.s. and An. arabiensis. 


\section{Background}

Malaria vector control strategies rely on the use of insecticides for the impregnation of bed nets and for indoor residual spraying. Increasing resistance of malaria vectors may have important implications for the vector control programmes, especially considering the scaling up of insecticide treated bed nets (ITNs). Hence, knowledge on changing trends in insecticide resistance is a basic requirement to guide the use of insecticides in the malaria control programmes.

Pyrethroids are the most commonly used insecticides in the fight against malaria. These insecticides modify the gating kinetics of the para-type sodium channels by slowing both the activation and the inactivation of the channels [1]. An important resistance mechanism against pyrethroids and DDT, known as knockdown resistance $(k d r)$, has been linked to a single mutation in the para-type sodium channel gene in several insect species [2]. Two different $k d r$ mutations have been found in the African malaria vector Anopheles gambiae s.s. In West Africa, knockdown resistance is linked with a mutation resulting in a leucine to phenylalanine substitution in the S6 segment of domain II of the para-type sodium channel (L1014F) [3]. In Kenya, however, a different mutation was found, causing a change from leucine to serine at the same amino acid position (L1014S) [4]. Recently, the leucine to phenylalanine mutation was found in An. arabiensis samples from Burkina Faso [5] and the leucine to serine mutation was found in the same species from Kenya [6].

In An. gambiae s.l. populations, the screening for the L1014S and L1014F $k d r$ mutation is commonly performed using two different allele-specific polymerase chain assays (AS-PCR) $[3,4]$. However, these techniques rely on a single nucleotide polymorphism mismatch at the 3 '-end of a primer, and can lead to unreliable results [7]. Recently, Lynd et al. [7] developed a Hot Oligonucleotide Ligation Assay (HOLA) for the detection of the $k d r$ mutations in An. gambiae s.s. This technique requires four separate hot ligation reactions to genotype specimens for the East and West African $k d r$ mutation [7]. In order to improve the detection of the $k d r$ mutations in An. gambiae s.s. and An. arabiensis a high-throughput test is needed that is able to detect both $k d r$ alleles simultaneously in one assay. Therefore, a new assay based on Fluorescence Resonance Energy Transfer/Melt Curve analysis (FRET/MCA) was developed and tested on field collected An. gambiae s.s. and An. arabiensis specimens from Uganda.

\section{Methods \\ Mosquito collections}

Mosquitoes were collected at monthly intervals from March 2001 to February 2002 in seven sites throughout Uganda (Okello, unpublished data). Three houses per site were chosen and human landing collections were done during six consecutive nights from $20.00 \mathrm{hr}$ until 06.00 $\mathrm{hr}$. The mosquitoes were morphologically identified using the key developed by Gillies and Coetzee [8] and were stored on silica gel.

\section{DNA extraction and molecular identification of species}

The protocol for DNA extraction is adapted from Vythilingam et al. [9]. Since collections were made in the frame of a transmission study (Okello, unpublished data), heads and thoraxes of individual mosquitoes were homogenized in $150 \mu \mathrm{l}$ blocking buffer [10] and $50 \mu$ l of blocking buffer/Nonidet P-40 (blocking buffer containing $0.5 \%$ Nonidet P-40). These enzyme linked immunosorbent assay (ELISA) homogenates were used for mosquito DNA extraction, by adding $200 \mu \mathrm{l}$ of a $20 \%$ Chelex solution (Biorad, Hercules, USA) to $20 \mu \mathrm{l}$ of the mosquito homogenate. Samples were placed in a thermo-mixer at $56^{\circ} \mathrm{C}$ and $1,400 \mathrm{rpm}$ for 30 minutes, vortexed at high speed for six seconds and placed in a thermo-mixer at $95^{\circ} \mathrm{C}$ and $1,400 \mathrm{rpm}$ for 10 minutes. After incubation, the samples were centrifuged twice at $13,400 \mathrm{~g}$ for five minutes at $4{ }^{\circ} \mathrm{C}$. The supernatants containing the DNA was transferred and stored at $-20^{\circ} \mathrm{C}$.

The protocol used for molecular identification of the members of the An. gambiae complex was adapted from Scott $e t$ al. [11]. Genomic DNA was mixed with the primers AR (specific for An. arabiensis), AG (specific for An. gambiae s.s.) and UN (common for both species) in a 25 $\mu \mathrm{l}$ reaction. Amplification reactions contained $1 \mu \mathrm{L}$ of DNA, $1.5 \mathrm{mM} \mathrm{MgCl}_{2}, 10 \mathrm{mM}$ Tris-HCl (pH 8.4), $50 \mathrm{mM}$ $\mathrm{KCl}, 0.1 \%$ Triton X-100, $200 \mu \mathrm{M}$ of dNTP's (Amersham, Buckinghamshire, United Kingdom), $80 \mathrm{nM}$ of primers $\mathrm{UN}$ and $\mathrm{AR}, 40 \mathrm{nM}$ of primer GA and $0.25 \mathrm{U}$ of Silverstar DNA polymerase (Eurogentec, Seraing, Belgium). The PCR was carried out as described in Scott et al. [11]. The amplified products were checked on a $2 \%$ agarose gel, stained with ethidium bromide, and visualized on the Image Master VDS (Amersham Pharmacia, Uppsala, Sweden).

AS-PCR for detection of the LIOI4S and LIOI4F kdr alleles The protocol used for the detection of the L1014S or L1014F $k d r$ alleles was adapted from the protocols developed by Martinez-Torres et al. [3] and Ranson et al. [4]. Primers Agd 1 (5'-atagattccccgaccatg-3'), Agd2 (5'-agacaaggatgatgaacc-3'), Agd3 (5'-aatttgcattacttacgaca-3') and Agd4 (5'-ctgtagtgataggaaattta-3') were used to detect the L1014F allele (AS-PCR Agd3), whereas primers Agd1, Agd2, Agd4 and Agd5 (5'-tttgcattacttacgactg-3') were used to detect the L1014S allele (AS-PCR Agd5) (Fig 1). Amplification was performed in a $50 \mu \mathrm{l}$ reaction containing $1 \mu \mathrm{l}$ of template DNA, $1 \times$ Qiagen PCR buffer, $0.5 \mathrm{mM} \mathrm{MgCl}_{2}$, $100 \mathrm{nM}$ of each primer, $200 \mu \mathrm{M}$ of dNTP's, and $1 \mathrm{U}$ of Taq 
A. AS-PCR Agd5 : detection of the East-African (L1014S) kdr allele

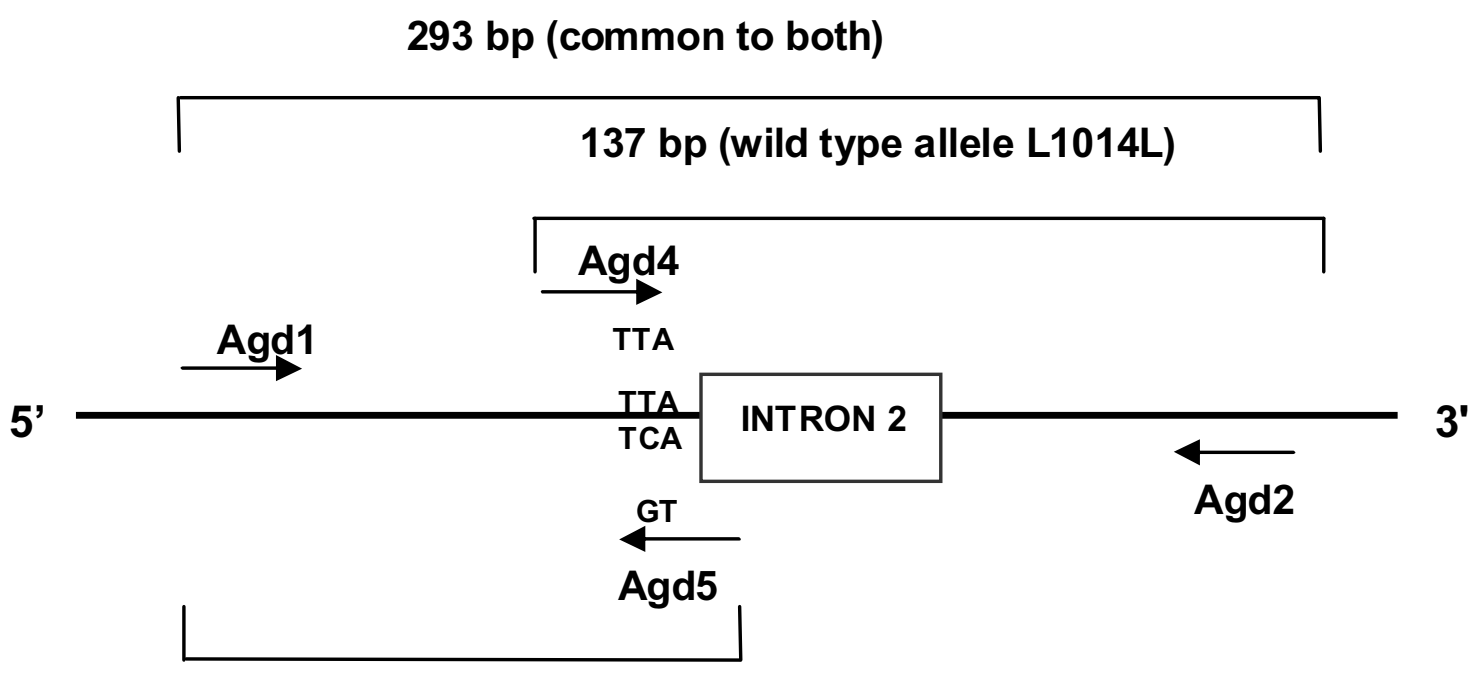

195 bp (L1014S kdr allele)

B. AS-PCR Agd3 : detection of the West-African (L1014F) kdr allele

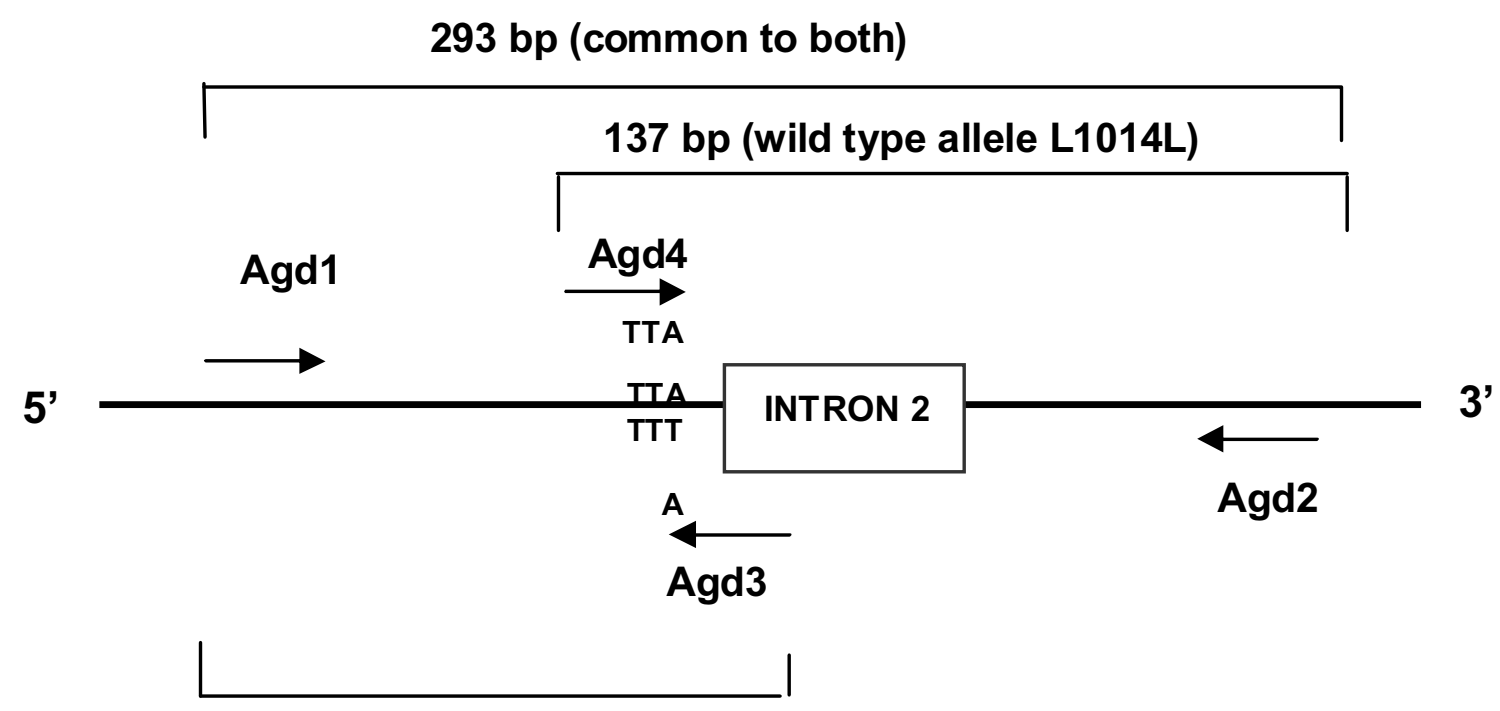

195 bp (L1014F kdr allele)

Figure I

Schematic representation of the AS-PCR Agd5 and AS-PCR Agd3. Schematic representation of the AS-PCR Agd5, which detects the LIOI4S kdr allele (A) and the AS-PCR Agd3, which detects the LIOI4F kdr allele (B) [3-4]. 
A

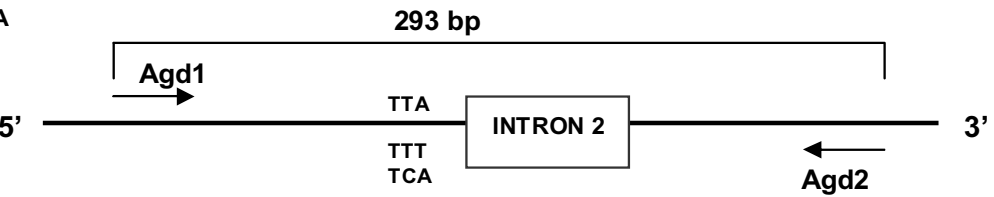

B

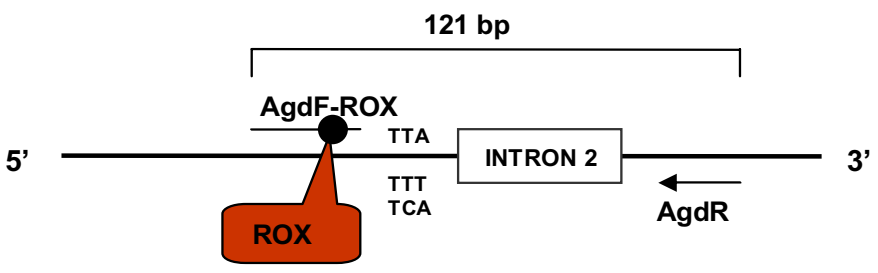

C

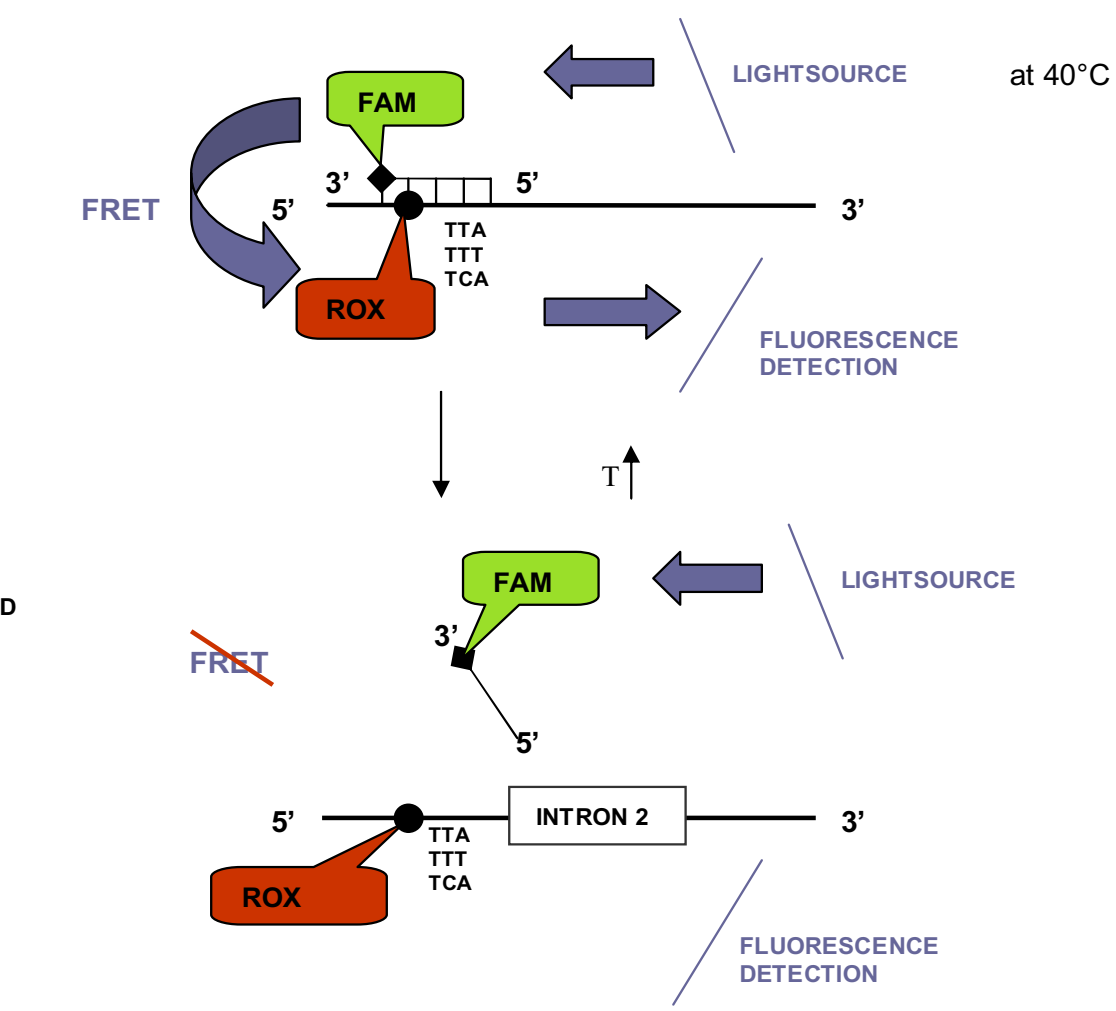

\section{Figure 2}

Schematic representation of the FRET/MCA, which allows the detection of both (LIO I4S and LIOI4F) kdr alleles in one assay. A. The primary PCR (primers AgdI-Agd2) results in amplification of a 293 bp fragment of the para-type sodium channel gene. B. During the secondary PCR, a 121 bp fragment is amplified and is labelled with ROX as the forward primer is extended. C. After amplification, the FAM-labelled probe hybridizes, and FRET starts to occur. The donor FAM-fluorophore is excited by incident light and because the ROX-acceptor is in close proximity, the excited state energy from FAM can be transferred. D. Melt curve analysis on the probe-amplicon hybrid. Progressive increase of temperature during melt curve analysis leads, at a specific temperature, to the dissociation of the probe from the amplicon. At this point, no FRET occurs and the ROX-fluorescence will decrease. During this MCA, the change in amount of fluorescence for each probe-template hybrid was plotted against the temperature and its negative derivative appeared as a positive peak. 
A

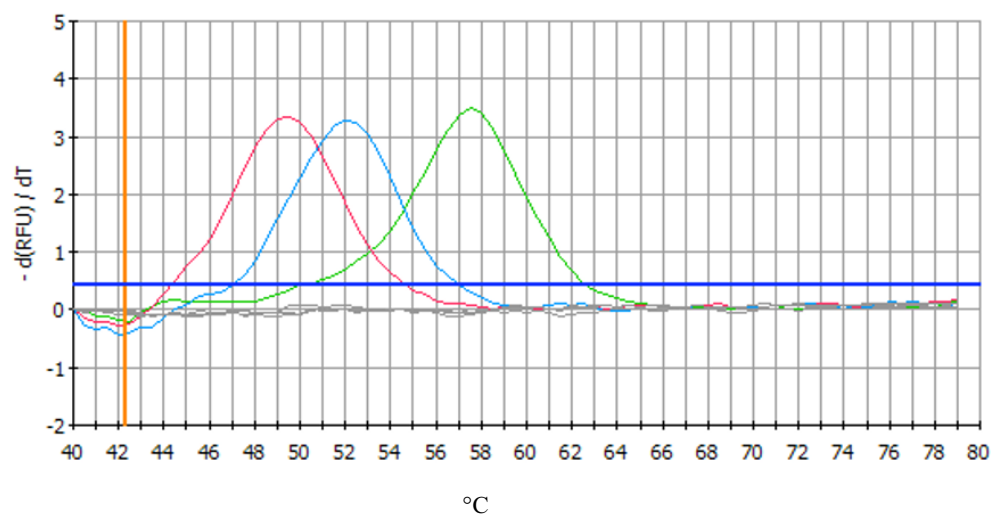

B

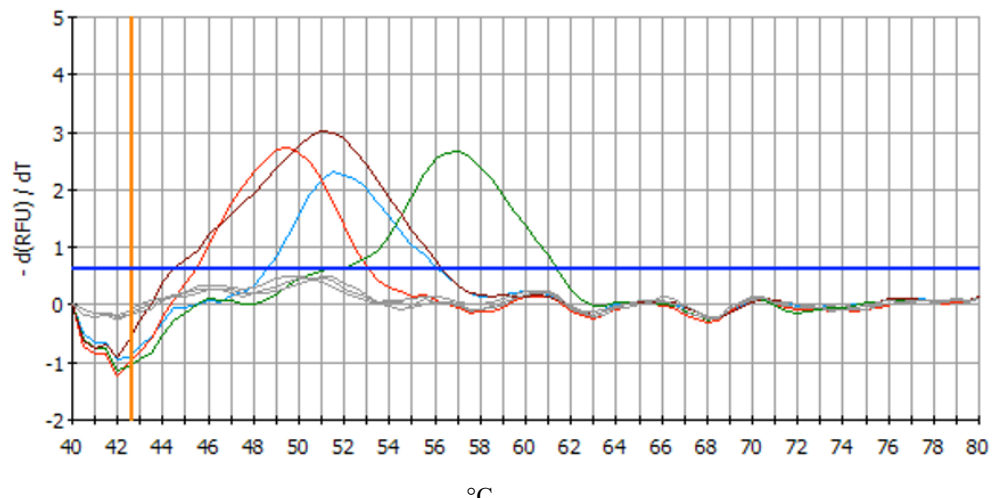

$\mathrm{C}$

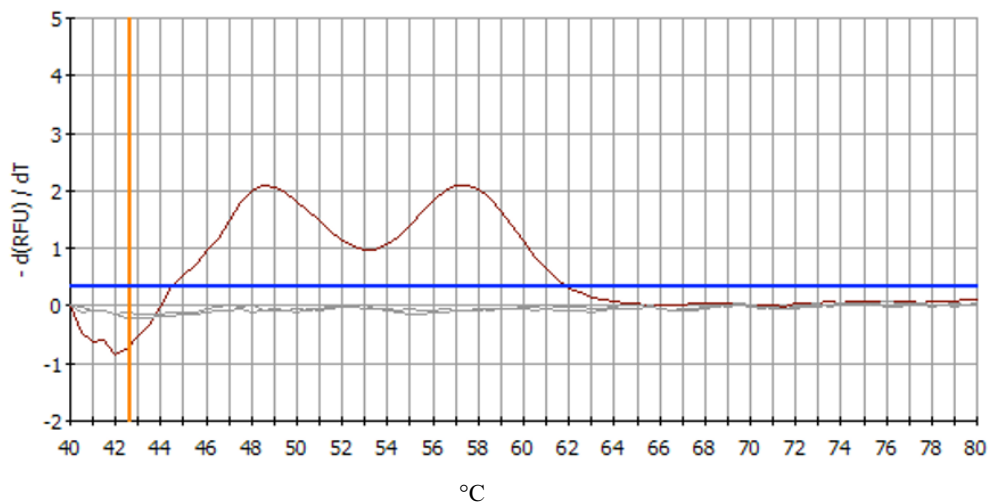

\section{Figure 3}

FRET/MCA of the DIIS6 region of the para-type sodium channel gene of An. gambiae s.s. and An. arabiensis plotted as the first negative derivative of the relative fluorescence unit (-d(RFU)/dT) versus temperature function. In all 3 panels, the thicker blue horizontal line denotes the threshold for background fluorescence, and the curve entirely below denotes the results for the non-template control (gray). A. Cloned sequence variants, from low to high $T_{m}$ : The LI0I4S allele (red), the LIOI4F allele (blue) and the wild type LIOI4L allele (green). Melting peaks were identified at $49.5^{\circ} \mathrm{C}, 52^{\circ} \mathrm{C}$ and $57.5^{\circ} \mathrm{C}$, respectively. B. An. gambiae s.s. specimens, from low to high $\mathrm{T}_{\mathrm{m}}$ : homozygous for the $\mathrm{LI} 0 \mathrm{I} 4 \mathrm{~S}$ allele, $\mathrm{T}_{\mathrm{m}}$ of $49.5^{\circ} \mathrm{C}$ (red) ; specimens heterozygous for both $k d r$ alleles (LIOI4S/LIOI4F allele), $\mathrm{T}_{\mathrm{m}}$ of $5 \mathrm{I}^{\circ} \mathrm{C}$ (dark red) ; specimens homozygous for LIOI 4F allele, $\mathrm{T}_{m}$ of $52^{\circ} \mathrm{C}$ (blue) and specimens homozygous wild type, $\mathrm{T}_{\mathrm{m}}$ of $57.5^{\circ} \mathrm{C}$ (green). C. An. gambiae s.s. specimens heterozygous for the LIOI4S/wild type (dark red) were characterised by two melting peaks of $49.5^{\circ} \mathrm{C}$ and $57.5^{\circ} \mathrm{C}$. Heterozygous (LI0I4S/wild type) An. arabiensis specimens showed the same pattern. 
DNA polymerase (Taq PCR core kit, Qiagen, Hilden, Germany). The cycling conditions were: initial $94^{\circ} \mathrm{C}$ denaturation for five minutes, 10 cycles of one minute denaturation at $94^{\circ} \mathrm{C}, 30$ seconds annealing at $54^{\circ} \mathrm{C}$ and 30 seconds extension at $72^{\circ} \mathrm{C}$, followed by 30 cycles of one minute denaturation at $94^{\circ} \mathrm{C}, 30$ seconds annealing at $47^{\circ} \mathrm{C}$ and 30 seconds extension at $72^{\circ} \mathrm{C}$, and a final extension at $72^{\circ} \mathrm{C}$ for 10 minutes. Amplification products were checked on a $2 \%$ agarose gel and visualized after ethidium bromide staining.

\section{FRETIMelt Curve analysis}

Primers and probes were designed using the Meltcalc software [12]. The forward primer AgdF-ROX (5'- tggccactgttgtgaTagg-3') is labelled with ROX, 4 nucleotides from the 3 '-end (Capital T), while the probe KDR-FAM (5'-tacttacgactaaatttcctat-3') is labelled with FAM, at its 3 '-end. The probe complements the wild type antisense strand of the PCR product. Two non-specific g's were added to the 5'end of the reversed primer AgdR (5'-ggtgacaaaagcaaggctaag-3') to increase the melting temperature and the GC-content of the primer.

A primary PCR was performed with a $50 \mu \mathrm{l}$ reaction mix containing $1 \mu \mathrm{l}$ of DNA, $1 \times$ Qiagen PCR buffer, $1 \mathrm{mM}$ $\mathrm{MgCl}_{2}, 200 \mu \mathrm{M}$ of each dNTP, $100 \mathrm{nM}$ of the primers Agd1 and Agd2 and $1 \mathrm{U}$ Taq DNA polymerase (Taq PCR core kit, Qiagen, Hilden, Germany). Amplification conditions were as follows: initial denaturation at $94^{\circ} \mathrm{C}$ for three minutes, forty cycles of one minute denaturation at $94^{\circ} \mathrm{C}, 30$ seconds annealing at $47^{\circ} \mathrm{C}$ and 30 seconds extension at $72^{\circ} \mathrm{C}$ followed by a final extension of 10 minutes at $72^{\circ} \mathrm{C}$ (Figure 2A).

The secondary PCR assay and the MCA were performed on an iCycler with a 490/20X FAM excitation filter and a 620/ $30 \mathrm{M}$ ROX emission filter (Bio-rad, Hercules, USA). The secondary PCR was performed in a 96-well plate. Amplification reactions $(50 \mu \mathrm{l})$ contained $1 \times$ iQ supermix (BioRad, Hercules, USA), $1 \mathrm{mM} \mathrm{MgCl}_{2}, 500 \mathrm{nM}$ of AgdF-ROX, $100 \mathrm{nM}$ of AgdR and $2 \mu \mathrm{l}$ of a 10 -fold dilution of the primary PCR product resulting from amplification with Agd1 and Agd2 (Figure 2B). Cycling conditions were as follows: initial denaturation at $95^{\circ} \mathrm{C}$ for four minutes, forty cycles of one minute denaturation at $95^{\circ} \mathrm{C}, 30$ seconds annealing at $52^{\circ} \mathrm{C}$ and 30 seconds extension at $72^{\circ} \mathrm{C}$ followed by a final extension at $72^{\circ} \mathrm{C}$ for eight minutes. During this asymmetric PCR, the target strand to which the FAMlabelled probe binds, was produced in excess. After amplification, the probe was added in a final concentration of $200 \mathrm{nM}$, and a melt curve was performed, consisting of $95^{\circ} \mathrm{C}$ for one minute, cooling to $40^{\circ} \mathrm{C}$ for one minute and 80 repeats heating for 20 seconds, starting at $40^{\circ} \mathrm{C}$ and with $0.5^{\circ} \mathrm{C}$ increments. During this melt curve, the cooling to $40^{\circ} \mathrm{C}$ will allow the FAM-labelled probe to anneal adjacent to the ROX-fluorophore of the PCR product (Figure $2 \mathrm{C}$ ). The temperature is subsequently slowly increased, while the ROX-fluorescence resulting from FRET, is continually monitored. When the melting temperature of the probe-amplicon hybrid is reached, FRET can no longer occur, and the ROX-fluorescence will decrease (Figure 2D). Changes in the ROX-fluorescence appear as a peak on the plot of the first negative derivative of the fluorescence versus temperature function. All data were analysed with the iCycler ${ }^{\mathrm{TM}}$ iQ Optical system software version 3.0a (Bio-rad, Hercules, USA). The experiments were performed in triplicate to verify reproducibility.

Three plasmids, containing as inserts the wild type, the L1014S or the L1014F $k d r$ allele, were used on each plate as positive controls. Two lines, a susceptible line and a homozygote resistant line for the West African $k d r$ allele L1014F, were obtained from laboratory colonies of the LIN/IRD and were used to construct the L1014L (wild type) and the L1014F plasmid, respectively. The L1014S plasmid originated from a sequenced homozygous L1014S field specimen of Uganda. The plasmids were constructed by ligation and transformation of the $293 \mathrm{bp}$ PCR product resulting from amplification with primers Agd1 and Agd2, by using the Original TA cloning kit according to the manufacturer's instructions (Invitrogen, Carlsbad, California). Three millilitres of each clone was purified on a column (QIAprep Spin Miniprep kit, Qiagen, Hilden, Germany) and DNA was resuspended in 50 $\mu \mathrm{l}$ water. Two microlitres of a 100 -fold dilution of the plasmid was used directly in the secondary, asymmetric PCR of the FRET/MCA assay instead of the template DNA. Plasmid and direct PCR sequencing were performed by the VIB genetic service facility (University of Antwerp, Belgium).

\section{Results}

Melt curve analysis of the plasmids produced three different melting curves with melting temperatures $\left(\mathrm{T}_{\mathrm{m}}\right)$ of approximately $49.5^{\circ} \mathrm{C}, 52^{\circ} \mathrm{C}$ and $57.5^{\circ} \mathrm{C}$ for the L1014S $k d r$ allele, the $\mathrm{L} 1014 \mathrm{~F} k d r$ allele and the wild type allele, respectively (Figure 3A). As expected, the wild type sequence DNA showed the highest melting temperature. The existence of a nucleotide mismatch between the target DNA and the hybridization probe produced a lower $T_{m}$ than the $\mathrm{T}_{\mathrm{m}}$ of the wild type sequence.

The melt curve obtained for mosquitoes homozygous for the L1014F, the L1014S or the wild type allele was identical to the melt curve obtained for the corresponding plasmid (Figure 3B).

Mosquito specimens, which were heterozygous for the L1014S/wild type, were characterised by two peaks with 


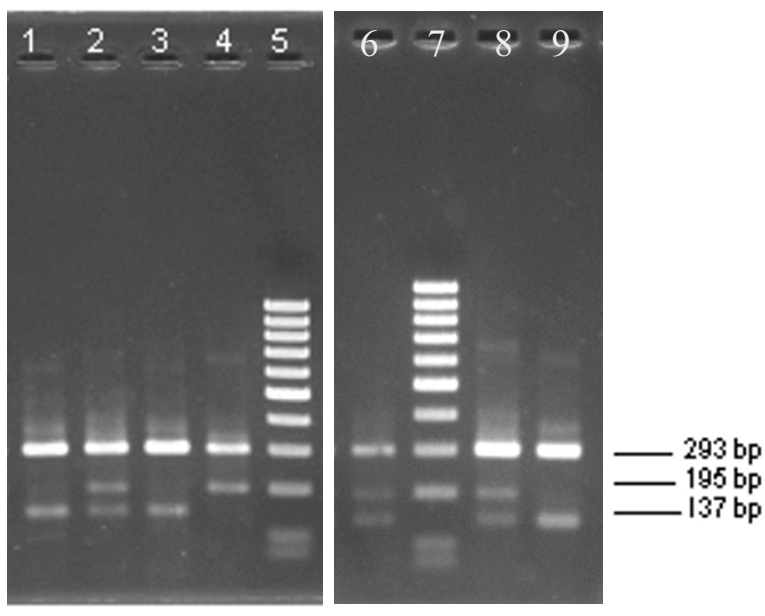

Figure 4

PCR products obtained using the AS-PCR Agd5 adapted from Ranson et al. [4] on An. gambiae s.s. after separation on a $2 \%$ agarose gel. Lane I, Lane 3 , Lane 9: homozygous wild type mosquitoes (LIOI4L/LIOI4L); Lane 2 and Lane 8: heterozygous specimens (LIOI4L/ LIOI4S); Lane 4: homozygous resistant specimen (LI0I4S/ LI0I4S); Lane 5 and Lane 7: 100 bp ladder; Lane 6: specimen scored as heterozygous (LI0I4L/LIOI4S) by AS-PCR, but scored as homozygous resistant (LIOI4S/LIOI4S) by FRET/ MCA.

$\mathrm{T}_{\mathrm{m}}$ of approximately $49.5^{\circ} \mathrm{C}$ and $57.5^{\circ} \mathrm{C}$ (Figure 3C). For the first time, two An. arabiensis specimens heterozygous for the L1014S/wild type mutation were found in Uganda [GenBank:DQ263749]. Four An. gambiae s.s. specimens produced a melting peak with a $\mathrm{T}_{\mathrm{m}}$ of approximately $51^{\circ} \mathrm{C}$, which was different from the expected $\mathrm{T}_{\mathrm{m}}$ for the wild type or the mutant alleles (Figure $3 \mathrm{~B}$ ). Cloning and sequencing of the $293 \mathrm{bp}$ fragment of domain II of the para-type sodium channel gene revealed that these specimens possess both, the L1014S and L1014F kdr allele, simultaneously [GenBank:DQ263748]. In theory, two peaks would be expected for these samples, one at $49.5^{\circ} \mathrm{C}$ and one at $52^{\circ} \mathrm{C}$. Instead, these samples showed a broad peak at $51{ }^{\circ} \mathrm{C}$, due to a too small difference in melting temperature between the L1014S and L1014F $k d r$ allele (Figure 3B).

The FRET/MCA results were compared with the two ASPCR assays for the detection of the West (L1014F) and East (L1014S) African $k d r$ mutation, i.e. AS-PCR Agd3 and AS-PCR Agd5. Therefore, 290 wild-caught An. gambiae s.s. and $183 \mathrm{An}$. arabiensis specimens from Uganda were tested by use of the three detection methods. By comparing the FRET/MCA and the AS-PCR Agd5 results, $121 \mathrm{An}$. gambiae s.s. and 181 An. arabiensis mosquitoes showed the same homozygote genotype for L1014L. Both assays
Table I: Comparison between the FRET/MCA and the AS-PCR Agd5. The AS-PCR Agd5 only detects the East African kdr mutation (LIOI4S).

\begin{tabular}{lccccc}
\hline Species & AS-PCR Agd5 & \multicolumn{5}{c}{ FRET/MCA } \\
\cline { 3 - 6 } & & S/S & S/RE & RE/RE & RE/RW \\
\hline An. gambiae s.s. & S/S & 121 & & & \\
& S/RE & 3 & 113 & 1 & \\
& RE/RE & & 6 & 38 & 4 \\
& negative & 2 & 2 & & \\
An. arabiensis & S/S & 181 & & & \\
& S/RE & & 2 & & \\
\hline
\end{tabular}

S: Wild type allele (LIOI4L)

RE: Resistant allele, East African mutation (LI0|4S)

RW: Resistant allele, West African mutation (LI0I4F)

showed the same heterozygous genotype L1014S/wild type for 113 An. gambiae s.s. and two An. arabiensis specimens and the same homozygous genotype for L1014S for 38 An. gambiae s.s. mosquitoes (Table 1). The four An. gambiae s.s. specimens, heterozygous for both $k d r$ alleles (L1014S/L1014F) were scored as homozygous L1014S in the AS-PCR Agd5. This is expected since the AS-PCR Agd5 should not detect the L1014F. Although the AS-PCR assays were adapted to give well interpretable results (Figure 4), there was discrepancy between the FRET/MCA and the AS-PCR Agd5 results for 10 An. gambiae s.s. specimens (Table 1). Sequence-analysis revealed that in all these cases the FRET/MCA method gave the correct result.

By comparing the FRET/MCA and the AS-PCR Agd3 results, 124 An. gambiae s.s. and 181 An. arabiensis mosquitoes showed the same homozygote genotype for L1014L (Table 2). In total, 119 An. gambiae s.s. and two An. arabiensis mosquitoes were scored homozygous wild type by AS-PCR Agd3, whereas they were scored as heterozygous L1014S/wild type by FRET/MCA. This is expected since the AS-PCR Agd3, designed for the detection of L1014F, should not detect the L1014S. However, 39 An. gambiae s.s. samples scored by FRET/MCA as homozygous for the East African $k d r$ mutation (L1014S/L1014S), were scored as homozygous susceptible by AS-PCR Agd3 (Table 2). The FRET/MCA results of these 39 An. gambiae s.s samples were confirmed by sequence analysis. Hence, when the AS-PCR Agd3 is performed on samples possessing the L1014S allele, primer Agd4 can mis-anneal to the L1014S allele and lead in combination with primer Agd2 to an erroneous amplification of a 137 bp PCR product, which is mis-recognized as a wild type allele. This non-specific annealing is not unlikely to occur in absence of a specific primer for L1014S, there is only one nucleotide mismatch between the second nucleotide from the 3'-end of primer Agd4 and the sequence of the L1014S allele (T-C mismatch) (Figure 1). 
Table 2: Comparison between the FRET/MCA and the AS-PCR Agd3. The AS-PCR Agd3 only detects the West African kdr mutation (LIO I 4F).

\begin{tabular}{lccccc}
\hline Species & AS-PCR Agd3 & \multicolumn{4}{c}{ FRET/MCA } \\
\cline { 3 - 5 } & & S/S & S/RE & RE/RE & RE/RW \\
\hline An. gambiae s.s. & $\begin{array}{c}\text { S/S } \\
\text { S/RW } \\
\text { RW/RW } \\
\text { negative }\end{array}$ & 124 & 119 & 39 & 2 \\
An. arabiensis & S/S & 181 & 2 & 2 \\
\hline
\end{tabular}

S: Wild type allele (LI0I4L)

RE: Resistant allele, East African mutation (LIOI4S)

RW: Resistant allele, West African mutation (LIOI4F)

Interestingly, the FRET/MCA was able to score 4 samples which were negative in both AS-PCR assays: two were homozygous susceptible and 2 heterozygous resistant for the L1014S allele. This indicates that the reliability of the AS-PCR can depend on the template concentration, while the FRET/MCA is less sensitive to changes in DNA template concentration.

\section{Discussion}

The ability to determine the resistance status of An. gambiae s.l. is essential to guide the use of insecticides in the African malaria control programmes. It allows for a rational choice of insecticide to be made, based on the type and extent of resistance present. Knockdown resistance has been detected in An. gambiae s.s. and An. arabiensis [3-6]. The screening for the L1014S and L1014F $k d r$ mutation, causing the knockdown resistance, is commonly performed using two different AS-PCR assays [3,4]. These assays provide a cheap mean for determining the $k d r$ allele frequencies in An. gambiae s.s. and An. arabiensis populations. Recently, Lynd et al. [7] developed a new assay based on HOLA for the detection of the $k d r$ alleles.

Here, a new high-throughput assay based on fluorescent hybridization and melt curve analysis for the detection of both $k d r$ mutations, is described. Although this FRET/ MCA technique requires a high initial equipment outlay, consisting of a standard PCR cycler equipped with an optical module, and requires expensive reagents, this technique offers several advantages over the existing methods.

First, the AS-PCRs rely only on a single nucleotide polymorphism at the 3'-end of the primer and can lead to unreliable results [7]. Although, the existing AS-PCR assays were adapted to obtain better interpretable results, there was still a discrepancy between the AS-PCR and the FRET/MCA results for 10 An. gambiae s.s. specimens (Table $1)$. In all these cases, the FRET/MCA method gave the correct result. Moreover, the FRET/MCA assay showed to be more sensitive and less depending on the template concentration than the existing AS-PCR assays.

Secondly, as new mutations arise at the probe-amplicon hybrid, these mutations are likely to be detected by the FRET/MCA assay. In contrast, the AS-PCR and the HOLA technique can only detect resistance alleles of known sequence. If other mutations arise, they need to be characterised at gene sequence level so that a new AS-PCR or HOLA assay can be developed, alongside the existing ones.

Finally, the major advantage of the FRET/MCA technique is its ability to screen simultaneously for both $k d r$ alleles in one well by the use of only one probe. In contrast, two AS-PCR assays (AS-PCR Agd3, AS-PCR Agd5) or 4 separate HOLA reactions are required to genotype specimens for both $k d r$ mutations. In addition, the FRET/MCA is designed to run in a 96-well format with integrated software to analyse the fluorescence data. In the initial development stage, samples were run in triplicate to verify reproducibility. Given the high reproducibility and ease of interpretation, up to 90 specimens can be screened for both $k d r$ alleles on a single microtitre plate, allowing fast screening of the $k d r$ mutations in a geographical region.

The FRET/MCA technique was applied on mosquitoes from Uganda to show its applicability in detecting $k d r$ alleles in field collected specimens. The assay worked well on DNA extracts from ELISA homogenates of mosquitoes as well as on simplified extracts of one mosquito leg (data not shown). The FRET/MCA could clearly distinguish between the different $k d r$ genotypes in An. gambiae s.s. and An. arabiensis specimens. The East African $k d r$ mutation (L1014S) was found in heterozygous state in An. arabiensis specimens from Uganda. Likewise, Stump et al. [6] had found the same mutation in An. arabiensis from Kisumu, a site close to one of the study sites in Uganda. Kdr seems to be present in low frequency in An. arabiensis. However, increased insecticide pressure can increase the $k d r$ frequency as was demonstrated in Kenya, where ITN introduction doubled the frequency of the L1014S $k d r$ allele in An. gambiae s.s. [6]. This points to the fact that highthroughput methods are needed for the monitoring of the $k d r$ allele.

Moreover, a new $k d r$ genotype has been found in An. gambiae s.s. from Uganda. In two collection sites in Uganda, An. gambiae s.s. mosquitoes were found to possess both the West (L1014F) and East (L1014S) African $k d r$ alleles, simultaneously. Interestingly, this West African $k d r$ allele (L1014F) was only found in combination with the East African $k d r$ allele (L1014S) in An. gambiae s.s. In all steps, from DNA extraction to FRET/MCA assay, appropriate negative controls were included. Moreover, the four heter- 
ozygotes originated from different localities and were extracted and tested on different days. Hence, contamination can be ruled out. The biological reason for the simultaneous occurrence of both mutations is subject of ongoing research. It is already clear that the presence of this West African $k d r$ mutation (L1014F) in Uganda has important implications for the monitoring of $k d r$ resistance in Africa. The reported absence of the L1014F in East African countries and of the L1014S in West African countries is probably due to the fact that in most cases only one or the other AS-PCR was used to detect $k d r$. In this way, the East African L1014S allele may perhaps been overlooked in West Africa. However, the present FRET/MCA survey clearly demonstrates that the West African L1014F allele also occurs in East Africa.

\section{Conclusion}

The FRET/MCA assay allows the genotyping of An. gambiae s.s. and $A n$. arabiensis specimens for both $k d r$ alleles by the use of only one probe. The assay results in clearly interpretable melting peaks for the different $k d r$ genotypes and works well on DNA extracts from ELISA homogenates as well as on simplified extracts of one mosquito leg. Moreover, the results show that the FRET/MCA is more reliable and more sensitive than the existing AS-PCR assays and is able to detect new genotypes. A new genotype was found in Uganda where four An. gambiae s.s. mosquitoes possessed both, the West (L1014F) and East (L1014S) African $k d r$ allele, simultaneously. The presence of both $k d r$ alleles in a same geographical region shows the necessity of a reliable assay that enables the detection of both $k d r$ alleles in one assay. Hence, this new highthroughput FRET/MCA assay will improve the screening of the $k d r$ frequencies in An. gambiae s.s. and An. arabiensis.

\section{Authors' contributions}

KV developed and carried out the FRET/MCA method, carried out the AS-PCR and drafted the manuscript. WVB and MC participated in the conception of the study, revised the work critically at all stages, and substantially helped to draft the manuscript. PR carried out the vast majority of the laboratory work. TB critically reviewed the manuscript.

\section{Acknowledgements}

We acknowledge the School of Medical Entomology in Kampala, Uganda, for the excellent entomological work and the Ministry of Health of Uganda for facilitating this research. We are grateful to the Laboratoire de Lutte contre les Insectes Nuisibles (LIN/IRD) of Montpellier for providing susceptible LI0I4L and homozygous resistant LI0I4F An. gambiae s.s. specimens. We thank Saskia Decuypere for excellent assistance in the design of this FRET/MCA assay.

This research received financial support from the Belgian Directorate-General for Development Cooperation and from a PAL + 2002 grant from the French Ministry of Research. This research was funded by a Ph.D. grant of the Institute for the Promotion of Innovation through Science and Technology in Flanders (IWT-Vlaanderen).

\section{References}

I. Lund AE, Narahashi T: Kinetics of sodium channel modification as the basis for the variation in the nerve membrane effects of pyrethroids and DDT analogs. Pestic Biochem Physiol 1983, 20:203-216.

2. Soderlund DM, Knipple DC: The molecular biology of knockdown resistance to pyrethroid insecticides. Insect Biochem Mol Biol 2003, 33:563-577.

3. Martinez-Torres D, Chandre F, Williamson MS, Darriet F, Berge JB, Devonshire AL, Guillet P, Pasteur N, Pauron D: Molecular characterization of pyrethroid knockdown resistance (kdr) in the major malaria vector Anopheles gambiae s.s. Insect Mol Biol 1998, 7:179-184.

4. Ranson $\mathrm{H}$, Jensen $B$, Vulule JM, Wang $X$, Hemingway J, Collins FH: Identification of a point mutation in the voltage-gated sodium channel gene of Kenyan Anopheles gambiae associated with resistance to DDT and pyrethroids. Insect Mol Biol 2000, 9:49I-497.

5. Diabaté A, Baldet T, Chandre F, Dabire KR, Simard F, Ouedraogo JB, Guillet P, Hougard JM: First report of a kdr mutation in Anopheles arabiensis from Burkina Faso, West Africa. J Am Mosq Control Assoc 2004, 20:195-196.

6. Stump AD, Atieli FK, Vulule JM, Besansky NJ: Dynamics of the pyrethroid knockdown resistance allele in Western Kenyan populations of Anopheles gambiae in response to insecticidetreated bed net trials. Am J Trop Med Hyg 2004, 70:59I-596.

7. Lynd A, Ranson H, McCall PJ, Randle NP, BlackIV WC, Walker ED, Donnelly MJ: A simplified high-throughput method for pyrethroid knock-down resistance (kdr) detection in Anopheles gambiae. Malar J 2005, 4:16.

8. Gillies MT, Coetzee M: A supplement to the anophelinae of Africa south of the Sahara (Afrotropical region). Publications of the South African Institute for Medical Research 1987:55.

9. Vythilingam I, Nitiaavathy K, Yi P, Bakotee B, Hugo B, Singh B, Palmer $\mathrm{K}$ : A highly sensitive, nested polymerase chain reaction based method using simple DNA extraction to detect malaria sporozoites in mosquitoes. Southeast Asian J Trop Med Public Health 1999, 30:631-635.

10. Wirtz RA, Sattabongkot J, Hall T, Burkot TR, Rosenberg R: Development and evaluation of an enzyme-linked immunosorbent assay for Plasmodium vivax -VK247 sporozoites. J Med Entomol 1992, 29:854-857.

II. Scott JA, Brogdon WG, Collins FH: Identification of single specimens of the Anopheles gambiae complex by the polymerase chain reaction. Am J Trop Med Hyg 1993, 49:520-529.

12. Schütz E, von Ashen N: Spreadsheet software for thermodynamic melting point prediction of oligonucleotide hybridization with and without mismatches. Biotechniques 1999, 27:1218-1224.

Publish with BioMed Central and every scientist can read your work free of charge

"BioMed Central will be the most significant development for disseminating the results of biomedical research in our lifetime. "

Sir Paul Nurse, Cancer Research UK

Your research papers will be:

- available free of charge to the entire biomedical community

- peer reviewed and published immediately upon acceptance

- cited in PubMed and archived on PubMed Central

- yours - you keep the copyright 